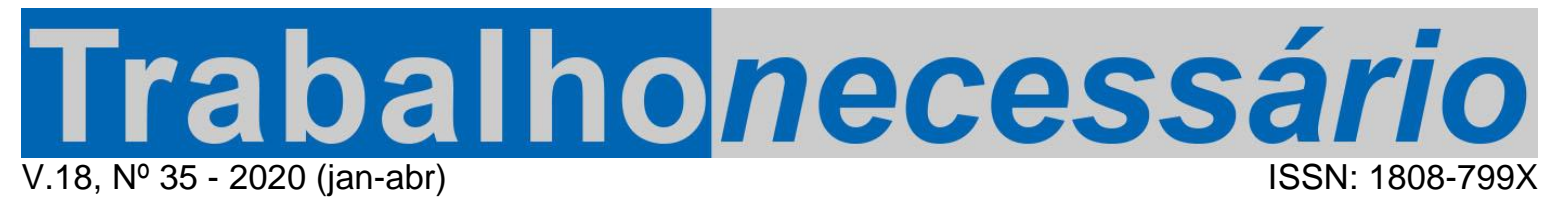

DOI: https://doi.org/10.22409/tn.v18i35.40490

\title{
“ESCOVAR A HISTÓRIA A CONTRAPELO": CONTRIBUIÇÕES DE WALTER BENJAMIN PARA A CONCEPÇÃO DIALÉTICA DA HISTÓRIA ${ }^{1}$
}

\author{
Vitor Bemvindo²
}

\section{Resumo}

A atual conjuntura de avanço do pensamento conservador e reacionário em todo mundo, obriga os historiadores marxistas a recuperar a essência da concepção dialética da história sem esbarrar em certas interpretações simplistas, etapistas, evolucionistas ou positivistas do materialismo histórico e dialético. Em tempos de avanço do obscurantismo, "clarear essa obscuridade" "é a honra da pesquisa histórica". Este artigo pretende recuperar o sentido dialético da concepção de história presente nas obras de Marx e Engels, a partir das contribuições do filósofo alemão Walter Benjamin. O estudo aqui proposto, pretende reconhecer, em especial, as elaborações em torno as ideias de "escovar a história a contrapelo" e de história aberta.

Palavras-chave: História, dialética, cultura, Walter Benjamin.

\section{"CEPILLAR LA HISTORIA A CONTRAPELO": CONTRIBUCIONES DE WALTER BENJAMIN A LA CONCEPCIÓN DIALÉTICA DE LA HISTORIA}

\section{Resumen}

La coyuntura actual del avance del pensamiento conservador y reaccionario en todo el mundo obliga a los historiadores marxistas a recuperar la esencia de la concepción dialéctica de la historia sin toparse con ciertas interpretaciones simplistas, escalonadas, evolucionistas o positivistas del materialismo histórico y dialéctico. En tiempos de avance del oscurantismo, "despejar esta oscuridad" "es el honor de la investigación histórica". Este artículo tiene como objetivo recuperar el significado dialéctico de la concepción de la historia presente en las obras de Marx y Engels, a partir de las contribuciones del filósofo alemán Walter Benjamin. El estudio propuesto aquí pretende reconocer, en particular, las elaboraciones en torno a las ideas de "cepillar la historia a contrapelo" y la historia abierta.

Palabra clave: Historia, dialéctica, cultura, Walter Benjamin.

\section{“TO BRUSH HISTORY AGAINST THE GRAIN": WALTER BENJAMIN'S CONTRIBUTIONS TO THE DIALETTIC CONCEPTION OF HISTORY}

\begin{abstract}
The current conjuncture of advancing conservative and reactionary thinking around the world forces marxist historians to recover the essence of the dialectical conception of history without bumping into certain simplistic, stepped, evolutionist, or positivist interpretations of dialectical and historical materialism. In times of advancement of obscurantism, "clearing this obscurity" "is the honor of historical research." This article aims to recover the dialectical meaning of the conception of history present in the works of Marx and Engels, from the contributions of the German philosopher Walter Benjamin. The study proposed here intends to recognize, in particular, the elaborations around the ideas of "to brush history against the grain" and open history.
\end{abstract}

Keywords: History, dialectic, culture, Walter Benjamin

1 Artigo recebido em 08/10/2019. Primeira avaliação em 15/11/2019. Segunda avaliação em 15/11/2019. Aprovado em 15/12/2019. Publicado em 23/01/2020.

2 Historiador e Doutor em Educação. Professor da Faculdade de Educação da Universidade Federal da Bahia.vitor.bemvindo@ufba.br ORCID: https://orcid.org/0000-0001-6472-2246 


\section{Introdução}

"Nunca há um documento da cultura que não
seja, ao mesmo tempo, um documento da
barbárie. E assim como ele não está livre da
barbárie, também não o está o processo de
sua transmissão, transmissão na qual ele
passou de um vencedor a outro. Por isso, o
materialista histórico, na medida do possível,
se afasta dessa transmissão. Ele considera
sua tarefa escovar a história a contrapelo".
Walter Benjamin

Desde a crise do socialismo real, há um esforço dentro do meio intelectual em apontar possíveis limites no modelo teórico de análise da realidade elaborado por Marx e Engels. O materialismo histórico dialético tem perdido espaço como referência teórico-metodológico nos trabalhos acadêmicos para tendências pós-modernas que resvalam em certo relativismo e ceticismo epistêmico. Como consequência dessa hegemonia pós-moderna, há a emergência de um pensamento que, ao mesmo tempo que reivindica o fim da modernidade enquanto período histórico, tende a negar a história. Ellen Wood afirma que, "a despeito de sua insistência em diferenças e especificidades que marcam épocas, a despeito de sua reivindicação de terem denunciado a historicidade de todos os valores e conhecimentos", os pós-modernos são "insensíveis à história" (WOOD, 1999, p. 14). Ainda segundo a autora, trata-se de uma contradição em termos: "uma teoria de mudança de época baseada na negação da história" (idem, p. 15).

Ao triunfalismo capitalista vigente após o fim da década 1980, somou-se a hegemonia das políticas econômicas de corte neoliberal, responsável por uma apropriação peculiar da história. Para Joseph Fontana, o neoliberalismo até admite a relação entre história e política, "porém sem levar em conta o filtro do presente". Sendo assim, a conexão entre esses dois aspectos se estabelece "no terreno das ideias, das concepções do mundo, sem que apareça viciada pelo contágio com interesses". Criase assim o mito da história imparcial, e admite-se o trabalho do historiador como uma análise isenta e sem influência das disputas pela hegemonia (FONTANA, 1998, p. 10).

A premissa da crítica às contribuições dos marxistas para o pensamento social gira em torno à categoria de totalidade e ao universalismo. Questiona-se, portanto, os 
modelos interpretativos fundamentados na história e decreta-se a crise da ciência histórica. Ignora-se, no entanto, uma série de reelaborações feitas no último século que permitiram ao marxismo aprofundar a análise da realidade a partir do abandono de concepções dogmáticas do materialismo histórico que se demonstraram limitadas diante da própria realidade. Autores como Antonio Gramsci, Walter Benjamim e E.P. Thompson foram alguns dos responsáveis por promover uma nova compreensão das ideias de Marx e Engels a partir de uma concepção dialética da história já presente nas obras originais do marxismo, porém que havia sido negligenciada pelo marxismo vulgar disseminado na primeira metade do século $\mathrm{XX}$.

A queda do dito socialismo real, o refluxo revolucionário e burocratização dos Estados operários abriram espaço para narrativas triunfalistas de que não há alternativas ao capitalismo e pela disseminação da tese do "fim da história". No campo acadêmico e político, as posições pós-modernas e neoliberais foram também responsáveis pelo declínio do pensamento crítico, que ajuda, pelo menos em parte, a explicar a crise das esquerdas na conjuntura atual. No entanto, a atualidade do materialismo histórico dialético está evidente nas contradições ainda não superadas dentro do próprio capitalismo que apontam para uma desigualdade social crescente e para um colapso ambiental.

Atualmente, uma nova onda de ataques ao pensamento crítico se acirra com a ascensão, em escala internacional, de grupos políticos ultraconservadores e reacionários. Com isso, volta-se a perceber uma tentativa de desqualificação do materialismo histórico e dialético como referência científica para trabalhos nas ciências humanas e sociais. Diante desta nova realidade emerge a necessidade de recuperar o sentido científico do pensamento marxista, porém sem resvalar na armadilha de certas interpretações simplistas, etapistas, evolucionistas ou positivistas.

Para isso, as contribuições do filósofo alemão Walter Benjamin para a concepção dialética da história se apresentam com grande atualidade. Para Michael Löwy:

A concepção da história de Benjamim não é pós-moderna, antes de tudo porque, longe de estar "muito além de todos os relatos" - supondo-se que isto seja possível - ela constitui uma forma heterodoxa do relato da emancipação: inspirando-se em fontes messiânicas e marxistas, ela utiliza a nostalgia do passado como método revolucionário de crítica do presente. Seu pensamento não é, então, nem "moderno" (no sentido habermasiano) nem 
"pós-moderno" (no sentido de Lyotard), inspirada em referências culturais e históricas pré-capitalistas (LÖWY, 2012, p. 15).

A despeito da heterodoxia do pensamento benjaminiano, acredita-se que suas contribuições para a concepção dialética da história colaboram de forma efetiva para a renovação do marxismo, em especial por retomar os aspectos dialéticos das elaborações originais de Marx e Engels. O presente artigo pretende analisar essas contribuições em especial, a partir das elaborações em torno às ideias de "escovar a história a contrapelo" e de história aberta. Este texto aprofunda reflexões presentes nas referências teórico-metodológicas da tese de doutorado "Por uma história da educação politécnica: concepções, experiências e perspectivas" (BEMVINDO, 2016), orientada pela professora Maria Ciavatta e defendida no ano de 2016 no Programa de Pós-Graduação em Educação da Universidade Federal Fluminense.

\section{A concepção dialética da história em Marx e Engels}

O pensamento de Marx e Engels foi apropriado, ao longo do tempo, das formas mais variadas possíveis. Seria impossível no espaço de um artigo, desenvolver como a ideia destes autores foram recebidas pelas mais diferentes tendências do marxismo. De certa forma, o que procuraremos fazer neste trabalho e olhar a concepção de história marxiana no sentido de encontrar os aspectos que afastem a ideia de uma história que apresentaria um certo padrão. Nas palavras de Leandro Konder, buscaremos nos afastar de uma certa "racionalidade da história que aponta para um sentido ascensional, por onde se infiltram, algumas vezes, algumas ideias do tipo evolucionista" (KONDER, 2014, p. 145). Essa racionalidade foi responsável por certa deturpação das ideias de Marx, atribuindo-as certo sentido teleológico. Veremos que este tipo de apropriação é derivado de uma interpretação limitada de trechos da obra de Marx e Engels que tratam especial da história como método. É preciso, portanto, compreender o duplo sentido da história na acepção marxiana: como processo e como método.

Maria Ciavatta (2009) nos auxilia na análise dessa concepção de história em Marx e Engels, afirmando que existem três caminhos para compreendê-la:

O primeiro é a defesa intransigente de uma ciência da história, principalmente em $A$ ideologia alemã. O segundo é a instituição da historicidade do social que só pode ser compreendida pela análise dialética, isto é, em sua gênese, seu desenvolvimento e 
transformação, como bem expressam sua Contribuição para a crítica da economia política e mesmo sua obra econômica, em que as relações econômicas são sempre, também, relações sociais. $O$ terceiro está em suas obras de história, a exemplo do clássico 018 Brumário de Luís Bonaparte. (CIAVATTA, 2009, p 52-53).

Baseado nesse apontamento, dedicaremo-nos, aqui, a compreender esses três aspectos da concepção de história em Marx e Engels, começando pela contida n'A ideologia alemã. Nessa obra, os autores originais do marxismo se dedicam a fazer uma análise crítica da obra de estudiosos do trabalho de Hegel na Alemanha, em especial Ludwig Feuerbach, Bruno Bauer e Max Stirner. Esses jovens hegelianos, segundo a análise de Marx e Engels, eram responsáveis pela disseminação de uma ideologia conservadora na Alemanha, já que tinham uma visão reduzida das contribuições filosóficas de Hegel, em especial do materialismo. O ponto central da crítica marxiana é a desconsideração que esses autores alemães fazem da história: "na medida em que Feuerbach é materialista, nele não se encontra a história, e na medida em que toma em consideração a história ele não é materialista. Nele, materialismo e história divergem completamente". (MARX, ENGELS, 2007, p. 32).

A partir dessa crítica, Marx e Engels se dedicaram a compreender o que é a história e como, a partir da ciência História, é possível fazer uma análise coerente da realidade concreta. O ponto de partida para a compreensão da concepção marxiana de história está no:

[...] primeiro pressuposto de toda a existência humana e também, portanto, de toda a história, a saber, o pressuposto de que os homens têm de estar em condições de viver para poder "fazer história". Mas, para viver, precisa-se, antes de tudo, de comida, bebida, moradia, vestimenta e algumas coisas mais. O primeiro ato histórico é, pois, a produção dos meios para a satisfação dessas necessidades, a produção da própria vida material, e este é, sem dúvida, um ato histórico, uma condição fundamental de toda a história (MARX, ENGELS, 2007, p. 32-33).

Marx e Engels destacarão ainda outros dois pontos pressupostos para a história. O segundo deles está no fato que a satisfação dessas necessidades primordiais gera novas necessidades. Por último, o terceiro pressuposto dá conta de que o homem tem a tendência de procriar-se, gerando, a partir das relações familiares, uma série de novas relações sociais que geram o crescimento populacional e a criação de novas necessidades. Esses três pressupostos, em conjunto, determinam 
que o movimento da história é dado pela própria produção material da vida. Em síntese:

\begin{abstract}
Essa concepção da história consiste, portanto, em desenvolver o processo real de produção a partir da produção material da vida imediata e em conceber a forma de intercâmbio conectada a esse modo de produção e por ele engendrada, quer dizer, a sociedade civil em seus diferentes estágios, como o fundamento de toda a história, tanto a apresentado em sua ação como Estado como explicando a partir dela o conjunto das diferentes criações teóricas e formas de consciência - religião, filosofia, moral etc. etc. - e em seguir o seu processo de nascimento a partir dessas criações, o que então torna possível, naturalmente, que a coisa seja apresentada em sua totalidade (assim como a ação recíproca entre esses diferentes aspectos) (MARX, ENGELS, 2007, p. 42).
\end{abstract}

Eric Hobsbawm (1999) nos auxilia a compreender essa assertiva de Marx e Engels quando recorre a Eric Wolf para entender o conjunto de relações engendradas pela produção da vida material:

Devemos notar, de passagem, que para Marx e Engels "o processo real de produção" não é simplesmente a "produção material da vida [imediata]" mas algo mais amplo. Para empregar a correta formulação de Eric Wolf, é "o conjunto complexo de relações mutuamente dependentes entre natureza, trabalho, trabalho social e organização social". Deve-se notar também que os seres humanos produzem tanto com a mão quanto com a cabeça (HOBSBAWM, 1999, p. 175).

A partir dessa distinção feita por Hobsbawm (com base em Wolf) pode-se inferir que existe uma relação dialética entre a produção e as formas de organização social. Essa relação é mais explorada quando Marx faz algumas considerações sobre o método em sua Contribuição para a Crítica da Economia Política. Será nessa obra que Marx deixará firmada a célebre e polêmica afirmação que até hoje alimenta os seus críticos: "não é a consciência que determina a vida, mas a vida que determina a consciência". Essa assertiva foi aprofundada no momento em que o autor descreveu as bases do seu método de análise da realidade:

O resultado geral a que cheguei e que, uma vez obtido, serviu-me de fio guia para os meus estudos, pode ser formulado, resumidamente, assim: na produção social da própria existência, os homens entram em relações determinadas, necessárias, independentes de sua vontade; essas relações de produção correspondem a um

3 A citação original traz "produção material da vida em si mesma" ao invés de "produção material da vida imediata". Alteramos a citação já que a tradução utilizada aqui da $A$ ideologia alemã (MARX, ENGELS, 2007) traz a segunda forma ao invés da primeira. 
determinado grau de desenvolvimento de suas forças produtivas materiais. A totalidade dessas relações de produção constitui a estrutura econômica da sociedade, a base real sobre a qual se eleva a superestrutura jurídica e política e à qual correspondem as formas sociais determinadas de consciência. O modo de produção da vida material condiciona o processo da vida social, política e intelectual. Não é a consciência dos homens que determina o seu ser; ao contrário, o seu ser social é que determina a sua consciência (MARX, 2008, p. 47).

Talvez a compreensão da concepção dialética da história, apesar de todas as notas de caráter teórico-metodológicas produzidas por Marx, Engels e seus seguidores, esteja mais evidente na análise das obras de cunho histórico desses autores. Dos autores originais do marxismo, talvez tenha sido Engels o que tenha mais se dedicado a trabalhos de análise histórica utilizando-se do método que os dois descreveram. Porém, o próprio Marx também se dedicou a trabalhos de pesquisa histórica, que talvez, nos dias atuais, recebessem a etiqueta de "história do tempo presente". Destacam-se na obra marxiana dois títulos com esse teor: 018 de Brumário de Luís Bonaparte e A Guerra Civil na França.

O foco deste trabalho não permite que nos dediquemos a uma interpretação mais profunda desses trabalhos. Por isso, para descrever os elementos de contribuição para análise histórica nessas obras, usaremos as próprias observações feitas por Marx e Engels sobre O 18 de Brumário de Luís Bonaparte. No prefácio da segunda edição ${ }^{4}$ do livro, o próprio Marx, ao comparar o seu trabalho com outros dois que tratam do mesmo tema - Napoleón le petit, de Victor Hugo, e Coup d'état, de Proudhon -, aponta para os avanços que sua obra em relação às demais:

Victor Hugo se limita a invectivas amargas e espirituosas contra o responsável pela deflagração do golpe de Estado. O acontecimento propriamente dito parece ser, para ele, como um raio vindo do céu sem nuvens. Ele vê no golpe apenas de um ato de poder de um indivíduo isolado. Não se dá conta de que engradece esse indivíduo, em vez de diminuí-lo, atribuindo-lhe uma capacidade de iniciativa pessoal que seria impar na história mundial. Proudhon, por sua vez, procura apresentar o golpe de Estado como resultado de uma evolução histórica precedente. Sorrateiramente, no entanto, a sua construção histórica do golpe de Estado se transforma numa apologia do herói do golpe de Estado. Desse modo, incorre no erro dos nossos assim chamados historiadores objetivos. Em contrapartida, eu demonstro

4 A primeira edição de $O 18$ de Brumário de Luís Bonaparte foi lançada em 1852, como primeiro fascículo da Revista Die Revolution. A segunda edição, de 1869, foi lançada para o mercado editorial europeu, com revisão do próprio Marx. Em 1885, saiu uma terceira edição da obra, com prefácio de Engels, sobre o qual faremos referência mais adiante. 
como a luta de classes na França criou circunstâncias e condições que permitiram a um personagem medíocre e grotesco desempenhar 0 papel do herói (MARX, 2011, p. 18).

Ao deixar a modéstia de lado, exaltando as qualidades de seu trabalho e demonstrando a limitação das análises de seus "colegas historiadores", Marx ressalta a importância do método descrito por ele e seu companheiro Engels. Apesar de não citar explicitamente as questões que envolvem a produção da vida material, ele dá ênfase a uma categoria de análise a qual nenhum historiador marxista pode se furtar a observar: a luta de classes.

Marx põe em prática, em sua análise sobre o golpe de Estado na França em 1851, a assertiva de cunho ético-político e metodológico que fizera em seu Manifesto Comunista - escrito em parceria com Engels -, a de que "a história de todas as sociedades até hoje existentes é a história da luta de classes" (MARX; ENGELS, 2010, p. 40). Ao observar as classes sociais que disputam a hegemonia em determinado momento histórico, Marx, de fato, historiciza o acontecimento, dando dimensão não só dos interesses políticos em jogo, mas também da organização social imposta pelo modo de produção hegemônico. Esse aspecto da obra marxiana foi ressaltada também por Engels, quando o mesmo prefaciou a terceira edição do "18 de Brumário".

Marx foi o primeiro a descobrir a grande lei da história, a lei segundo a qual todas as lutas históricas travadas no âmbito político, religioso, filosófico ou em qualquer outro campo ideológico são de fato apenas a expressão mais ou menos nítida de lutas entre classes sociais, a lei segundo a qual a existência e, portanto, também as colisões entre essas classes são condicionadas, por sua vez, pelo grau de desenvolvimento da sua condição econômica, pelo modo da sua produção e pelo modo do seu intercâmbio condicionado pelo modo de produção. Essa lei - que para história tem a mesma importância que a lei da transformação de energia para a ciência natural -, essa lei lhe proporcionou, também nesse caso, a chave para uma compreensão da história da Segunda República francesa. E essa história Ihe serviu para submeter a sua lei à prova, tanto é que, trinta e três anos depois, ainda temos de reconhecer que ela passou no teste com brilhantismo (ENGELS, 2011, p. 22).

Engels utilizou essa "lei" também em seus trabalhos de pesquisa histórica e dedicou toda uma das suas obras, o Anti-Dühring, a fazer apontamentos de ordem teórico-metodológica sobre a escrita da história, ao fazer a crítica do trabalho do filósofo alemão Eugen Dühring. Engels acusava Dühring de ter sua compreensão dos processos históricos limitados por conta do mesmo não observar os aspectos da luta 
de classes e da consequente divisão social do trabalho. Nessa obra, ele atribui à economia política o status de "ciência histórica" e por algumas vezes reforça a comparação entre essa ciência e as ciências naturais. O mesmo o faz em Do Socialismo Utópico ao Socialismo Científico.

Talvez essas afirmações tenham sido responsáveis pela equivocada interpretação que, no marxismo, a história obedece a padrões e que se seguido o método à risca seria possível, inclusive, prever o desenvolvimento da história no futuro. Isso é uma evidente distorção do materialismo histórico e dialético, que se perpetuou dentro mesmo dos círculos de pensamento marxistas em especial após a Terceira Internacional. Essa distorção fez com muitos historiadores passassem a ter uma visão etapista da história.

Mais uma vez, Eric Hobsbawm nos dá subsídio de como fugir dessa concepção distorcida e limitada do materialismo histórico e dialético. O historiador britânico, mesmo nunca se desvinculando da sua filiação com o Partido Comunista da GrãBretanha $^{5}$, soube, sabiamente, fazer a crítica das limitações interpretativas feitas a partir do trecho supracitado da Contribuição para a crítica da economia política, dando elementos para análise histórica de caráter mais amplo:

A formulação mais completa [da concepção materialista da história] ocorre no Prefácio de 1859 à Para a crítica da economia política. Claro que é preciso perguntar se é possível rejeitá-la e continuar sendo marxista. Porém, é perfeitamente claro que essa formulação ultraconcisa requer elaboração: a ambiguidade de seus termos suscitou debate sobre o que exatamente são "forças" e "relações sociais" de produção, o que constitui a "base econômica", a "superestrutura" e assim por diante. Também está perfeitamente claro desde o início que, uma vez que os seres humanos possuem consciência, a concepção materialista da história é a base da explicação histórica mas não a explicação histórica em si. A história não é como a ecologia: os seres humanos decidem e refletem sobre o que acontece. Não está tão claro se ela é determinista no sentido de nos permitir descobrir o que inevitavelmente acontecerá, enquanto distinto dos processos gerais de transformação histórica. Isso porque é somente numa visão retrospectiva que a questão da inevitabilidade histórica pode ser solidamente estabelecida, e mesmo então apenas como tautologia: o que aconteceu era inevitável porque não aconteceu outra coisa; portanto, o que poderia ter acontecido é uma questão acadêmica (HOBSBAWM, 1999, p 175).

5 O Partido Comunista da Grã-Bretanha, fundado em 1920, após a Terceira Internacional, foi um dos principais responsáveis pela disseminação das interpretações stalinistas sobre o materialismo histórico e dialético no mundo ocidental. 
Hobsbawm reforça a ideia de que Marx almejava provar que o desenvolvimento das forças produtivas levaria inevitavelmente ao comunismo, no entanto, ele nunca se utilizou da história para provar essa tese. Não há elementos científicos, dentro do materialismo histórico e dialético que apontem especificamente para o comunismo. Além disso, esses apontamentos do historiador britânico nos dão elemento para refutar a tese do determinismo economicista pelo qual Marx foi e segue equivocadamente sendo acusado. Para Hobsbawm, o cerne da concepção materialista da história está na "relação fundamental entre o ser social e a consciência". Ele reforça a ideia de a distinção entre base e superestrutura se dá apenas na dimensão retrospectiva da análise histórica e que existem sociedades que, sob as mesmas bases materiais, estruturam suas relações sociais de formas distintas. Ou seja, o autor reforça a dimensão da totalidade histórica que é constituída por múltiplas determinações. Para ele isso fica evidente na análise das obras de caráter histórico de Marx, nas quais é possível notar a consideração dessas múltiplas determinações, sendo essas análises um "oposto exato de um reducionismo econômico" (ib., p. 176).

Ainda assim, Hobsbawm não nega a importância da análise dos elementos de ordem econômica. Ao contrário, ele reforça que

a análise de uma sociedade, a qualquer momento de seu desenvolvimento histórico deve começar pela análise de seu modo de produção: em outras palavras, (a) a forma tecno-econômica do "metabolismo entre homem e natureza" (Marx), o modo pelo qual o homem se adapta a natureza e a transforma pelo trabalho; e (b) os arranjos sociais pelos quais o trabalho é mobilizado, distribuído e alocado (ib., p 177).

Por fim, entre as inúmeras contribuições de Hobsbawm para a compreensão da concepção materialista da história, destaca-se a ampliação que o historiador britânico faz do conceito de modo de produção. O autor destaca que há uma visão equivocada na interpretação de que existe um encadeamento lógico e inevitável entre a superação de um modo de produção e constituição de um novo modo de produção historicamente mais "evoluído". Ele ressalta que essa sucessão de modos de produção não pode ser encarada como meramente evolutiva, cronológica e unilinear. Essa interpretação desconsideraria, por exemplo, a coexistência e interação de modos de produção distintos num mesmo momento histórico. 
A ideia central da interpretação de Hobsbawm sobre essa categoria está na ideia de que dentro de cada modo de produção "há uma 'contradição básica' que gera a dinâmica e das forças que o levarão a sua transformação". Isso, no entanto, não implica na certeza da transformação desses modos de produção, mas na potencialidade dessa transformação (ib., p.180-181).

Nessa perspectiva, acreditamos que Walter Benjamin contribui de forma decisiva para a compreensão da concepção dialética da história numa acepção mais ampla do que a disseminada pelo dito marxismo vulgar. Benjamin, ao se dedicar aos estudos sobre a cultura, ajudou a ampliar os domínios do materialismo histórico e dialético.

\section{A concepção dialética da história em Benjamin}

Walter Benjamin faz uma crítica bastante pertinente aos historiadores em geral e dos pensadores marxistas em particular por conta da pouca familiaridade que os mesmos têm com os aspectos culturais do desenvolvimento histórico. Baseado também nas concepções de classe social e luta de classes elaboradas por Marx e Engels, Benjamin convida-nos a escrever uma História que valorize as lutas das classes historicamente postas em posição subalterna. Trata-se da quarta das "Teses Sobre o Conceito de História", texto publicado em 1940, no qual Benjamin faz algumas das mais profundas reflexões e provocações sobre a concepção materialista e dialética, dentre as quais a que se segue:

\footnotetext{
A luta de classes, que um historiador educado por Marx jamais perde de vista, é uma luta pelas coisas brutas e materiais, sem as quais não existem as refinadas e espirituais. Mas na luta de classes essas coisas espirituais não podem ser representadas como despojos atribuídos ao vencedor. Elas se manifestam nessa luta sob a forma da confiança, da coragem, do humor, da astúcia, da firmeza, e agem de longe, do fundo dos tempos. Elas questionarão sempre cada vitória dos dominadores. Assim como as flores dirigem sua corola para o sol, o passado, graças a um misterioso heliotropismo, tenta dirigir-se para o sol que se levanta no céu da história. O materialismo histórico deve ficar atento a essa transformação, a mais imperceptível de todas (BENJAMIN, 1996, p. 223-224).
}

Benjamin se utiliza de uma retórica recheada de ironias para chamar a atenção dos historiadores marxistas para elementos que normalmente são negligenciados nas 
análises. O uso dos termos "coisas brutas e materiais" em oposição às "refinadas e espirituais" é um evidente recurso utilizado para chamar atenção para que não só de comida vive o trabalhador, o oprimido. Isso, aliás, não é uma conclusão original de Benjamin. Como já foi dito nesse mesmo trabalho, Marx e Engels já afirmavam que "a satisfação dessa primeira necessidade [a produção da vida material imediata], a ação de satisfazê-la e o instrumento de satisfação já adquirido conduzem a novas necessidades" (MARX, ENGELS, 2007, p. 33). Para os autores originais do marxismo, o segundo ato histórico, por mais que seja determinado do primeiro (a produção da vida material imediata) é a produção de novas necessidades, podendo-se inferir que a esfera da produção da cultura está a esse ato relacionado.

No entanto, Benjamin avança no que se refere às proposições de Marx e Engels, pois compreende que a conquista do poder pela classe dominante não se dá apenas a partir da dominação econômica. Há um elemento que o Marx e Engels abordaram de forma menos detida que diz respeito à produção de ideologia na tentativa de subjugar as classes trabalhadoras a uma condição de subalternidade. No entanto, é óbvio que os trabalhadores não aceitam esse subjugo passivamente. Eles também produzem a sua ideologia, que entra em disputa com a hegemônica.

O que Benjamin nos chama a atenção é de que nesse processo de disputa entre as classes sociais antagônicas há produção de cultura dos dois lados, por mais que os historiadores negligenciem a cultura dos "vencidos". Essa tese benjaminiana sobre a história se complementa muito bem com as disputas de hegemonia tão bem ressaltadas por Gramsci. Subsidiária das reflexões de Gramsci, as categorias de contra-hegemonia e hegemonia alternativa - elaboradas por Raymond Williams - nos dão elementos para compreender esse elemento cultural e ideológico da luta de classes no contexto da análise histórica.

Uma hegemonia vivida é sempre um processo. Não é, exceto analiticamente, um sistema ou uma estrutura. É um complexo realizado de experiências, relações e atividades, com pressões e limites específicos e mutáveis. Isto é, na prática a hegemonia não pode nunca ser singular. Suas estruturas internas são altamente complexas, e podem ser vistas em qualquer análise concreta. Além do mais (e isso é crucial, lembrando-nos o vigor necessário do conceito), não existe apenas passivamente como forma de dominação. Tem de ser renovada continuamente, recriada, defendida e modificada. Também sofre uma resistência continuada, limitada, alternada, desafiada por pressões que não são as suas próprias pressões. Temos então de acrescentar ao conceito de hegemonia o conceito de contra- 
hegemonia e hegemonia alternativa, que são elementos reais e persistentes da prática (WILLIAMS, 1979, p. 115-116).

A complementaridade das ideias de Benjamin, Gramsci e Williams nos fazem olhar para a história pelo prisma da luta de classes, mas compreendendo que nesse processo há mais do que simplesmente a disputa pelo controle dos meios de produção ou do que a transformação do modo de produção. Há, também, nesse embate, produção de cultura e contracultura, disputa de hegemonia e produção de pensamentos contra-hegemônicos. Não observar esses aspectos na análise histórica é não perceber as contradições do processo de desenvolvimento das forças produtivas. Desta ideia emerge a tese benjaminiana sobre escovar a história a contrapelo:

Todos os que até hoje venceram participam do cortejo triunfal, em que os dominadores de hoje espezinham os corpos dos que estão prostrados no chão. Os despojos são carregados no cortejo, como de praxe. Esses despojos são o que chamamos bens culturais. $O$ materialista histórico os contempla com distanciamento. Pois todos os bens culturais que ele vê têm uma origem sobre a qual ele não pode refletir sem horror. Devem sua existência não somente ao esforço dos grandes gênios que os criaram, como à corveia anônima dos seus contemporâneos. Nunca houve um monumento da cultura que não fosse também um monumento da barbárie. E, assim como a cultura não é isenta de barbárie, não o é, tampouco, o processo de transmissão da cultura. Por isso, na medida do possível, o materialista histórico se desvia dela. Considera sua tarefa escovar a história a contrapelo (BENJAMIN, 1996, p. 225).

Assumir essa tese de Walter Benjamin sobre a história é assumir uma posição política clara em favor da construção de horizontes interpretativos que privilegiem os saberes acumulados durante a longa luta dos povos oprimidos.

Outro aspecto fundamental da contribuição benjaminiana é o reforço do caráter dialético da história, através de uma revisão da ideia de totalidade. Konder ressalta que Benjamin propôs forma própria de lidar com a totalidade, entendendo-a como uma visão de conjunto transitória determinada pela relação dialética entre presente e passado.

A grande dificuldade do pensamento dialético é promover a reestruturação permanente e radical do todo, que não é uma operação simples, nem é uma operação agradável. É uma operação delicada, difícil. Para tanto, tem que haver uma revisão de convicções enraizadas, coisas construídas com esforço, que foram assimiladas com paixão. Então, na visão benjaminiana, inclui-se uma ação 
importante, que é a revalorização da totalidade. (KONDER, 2014, p. 165)

Essa revalorização da totalidade construída a partir da relação dialética entre presente e passado está expressa por Benjamin na quinta das suas "Teses sobre a história", que diz:

\begin{abstract}
A verdadeira imagem do passado passa célebre e furtiva. É somente como imagem que lampeja justamente no instante de sua recognoscibilidade, para nunca mais ser vista, que o passado tem de ser capturado tem que ser capturado. "A verdade não nos escapará" essa frase de Gottfried Keller indica, na imagem que o historicismo faz da história, exatamente o ponto em que ela é batida em brecha pelo materialismo histórico. Pois é uma imagem irrestituível do passado que ameaça a desaparecer com cada presente que não se reconhece nela visado (BENJAMIN apud LÖWY, 2012, p. 62).
\end{abstract}

Esta tese aponta para a "abertura da história", promovida por Benjamin, que permitiu ao marxismo escapar das análises etapistas presentes numa interpretação vulgar das obras de Marx e Engels. No entanto, Michael Löwy destaca que essa apreensão sobre a concepção dialética da história benjaminiana é feita a partir de "uma herança marxista altamente seletiva" que prescinde dos trechos a obra marxiana que "serviram de referência às positivistas/evolucionistas do marxismo". Benjamin abre mão das ideias de "progresso irresistível", de "leis da história" e de "fatalidade natural" para ressaltar o aspecto dialético que existe entre presente e passado na escrita da história (LÖWY, 2012, p. 147).

Sem dúvida, a obra de Marx e Engels é atravessada por tensões irresolutas entre um certo fascínio pelo modelo científico-natural e uma conduta dialética - crítica -; entre a fé no amadurecimento orgânico e quase natural do processo social e a visão estratégica da ação revolucionária que apreende um momento excepcional. Essas tensões explicam a diversidade dos marxismos que disputam entre si a herança após a morte de seus fundadores. Nas teses de 1940, Benjamin ignora o primeiro polo do espectro de Marx e se inspira no primeiro (idem, p. 148).

A proposição de uma história aberta de Benjamin inaugura um "marxismo da imprevisibilidade" e a busca por uma racionalidade dialética que "recusa as armadilhas da 'previsão científica' de gênero positivista” (idem, p. 150). Löwy ressalta, no entanto, que "a imprevisibilidade é certamente apenas relativa", já que de certa forma existe a possibilidade de se inferirem movimentos da história a partir da sua análise 
processual. Porém, "ao contrário dos eclipses da lua ou da próxima passagem do cometa Halley, o resultado da ação histórica dos indivíduos e dos grupos sociais continua consideravelmente imprevisível" (idem).

Joseph Fontana destaca como a experiência do nazifascismo foi crucial para a concepção de história aberta proposta por Benjamin. Para ele, a imprevisibilidade da ascensão de regimes altamente reacionários em um momento histórico de avanço da organização dos trabalhadores e dos movimentos políticos de esquerda marca a forma de ver a história de Benjamin. Sendo assim, o filósofo alemão "propunha ao historiador que trabalhasse como o físico na desintegração do átomo, com o fim de liberar as enormes forças que ficam presas na explicação linear da história" que teria sido, para ele, "o narcótico mais poderoso" do século XX (FONTANA, 1998, p. 277).

\section{À guisa de conclusão}

A atual conjuntura de avanço do pensamento conservador e reacionário em todo mundo, obriga os historiadores marxista a recuperar a essência da concepção dialética da história sem esbarrar em certas interpretações simplistas, etapistas, evolucionista ou positivista do materialismo histórico e dialético. Em tempos de avanço do obscurantismo, "clarear essa obscuridade" "é a honra da pesquisa histórica". (LÖWY, 2012, p. 51).

Para isso, as lições de autores como Walter Benjamin e sua resistência ao economicismo e mecanicismo vulgar são cada vez mais úteis na construção de uma referência crítica para a História. Neste ponto, Benjamin se encontra com Antonio Gramsci e E. P. Thompson, responsáveis pela renovação do marxismo durante o século XX. Os três autores abriram caminho para uma interpretação da história que não abre mão da dialética. Para isso é importante a apropriação de categorias fundamentais do pensamento dialético como totalidade, mediação e contradição.

Em especial sobre a categoria totalidade, Benjamin traz contribuições fundamentais para a compreensão dialética entre presente e passado, reforçando a ideia que a totalidade é apenas um momento da visão de conjunto que é sempre transitória. Para isso, surge a necessidade de identificar as "contradições concretas e as mediações específicas que constituem o 'tecido' de cada totalidade" (KONDER, 1984, p. 46). 
É nesse sentido de enfrentamento aos determinismos que a obra de Benjamin, Gramsci e Thompson se encontram a parir da constatação que o materialismo histórico de Marx e Engels é "constatativo e não normativo", tal qual ressalta Leandro Konder:

\begin{abstract}
nas condições de insuficiente desenvolvimento das forças produtivas humanas e de divisão da sociedade de classes, a economia tem imposto, em última análise, opções estreitas aos homens que fazem a história. Isso não significa que a economia seja o sujeito da história, que a economia vai dominar eternamente os movimentos do sujeito humano. Ao contrário: a dialética aponta na direção de uma libertação mais efetiva do ser humano em relação ao cerceamento de condições de econômicas ainda desumanas (idem, p. 68-70).
\end{abstract}

Sendo assim, vale ressaltar os pontos de contato entre as contribuições de Gramsci e Benjamin. Ambos deram atenção aos elementos da cultura e da ideologia como fundamentais para a construção da hegemonia. Apesar do filósofo alemão não se valer diretamente desta categoria gramsciana, há evidentes congruências no pensamento de ambos na percepção dialética da história. Sem abrir mão das categorias fundamentais do método proposto por Marx e Engels, em especial da categoria classe social, Gramsci aponta elementos de como um historiador marxista pode tentar dar conta das múltiplas determinações de uma totalidade histórica.

Pelo menos como orientação metodológica, deve-se chamar a atenção para as outras partes da história da filosofia; isto é, para as concepções de mundo das grandes massas, para as dos mais restritos grupos dirigentes (ou intelectuais) e, finalmente, para as ligações entre estes vários complexos culturais e a filosofia dos filósofos. A filosofia de uma época não é a filosofia deste ou daquele filósofo, deste ou daquele grupo de intelectuais, desta ou daquela grande parcela das massas populares: é uma combinação de todos esses elementos, culminando em uma determinada direção, na qual sua culminação torna-se norma de ação coletiva, isto é, torna-se "história" concreta e completa (integral) (GRAMSCI, 1978, p. 31).

Assim como Gramsci, Benjamin ressalta a importância de compreender a história não apenas através dos determinantes materiais. Surge então o desafio ao historiador marxista de compreender a luta de classes não apenas como "uma luta pelas coisas brutas e materiais", mas também pelas "coisas materiais" (BENJAMIN, 
1996, p. 223-224). O autor alemão destaca a necessidade de integrar a história da cultura à história da luta de classes.

Deste desafio de compreender a cultura e a ideologia como elementos fundamentais da luta de classes, emerge um segundo desafio, o de perceber o movimento da história não apenas como o "cortejo triunfal dos vencedores dos dominadores". Sendo assim, Benjamin recusa qualquer identificação afetiva com os heróis oficiais, interessando por escrever a história no sentido contrário, tal qual salienta Michael Löwy:

Benjamin se interessa pela salvaguarda das formas subversivas e antiburguesas da cultura, procurando evitar que sejam embalsamadas, neutralizadas, tornadas acadêmicas e incensadas pelo establishment cultural. É preciso lutar para impedir que a classe dominante apague as chamas da cultura passada, e para que elas sejam tiradas do conformismo que as ameaça (LÖWY, 2012, p. 8).

A tese de Benjamin sobre a abertura da história pressupõe, portanto, "uma opção ética, social e política pelas vítimas da opressão e por aqueles que a combatem" (idem, p. 159). Esta ideia coincide com a assertiva de Hobsbawm de que "a história pode ter vencedores a curto prazo, mas os ganhos históricos vêm dos vencidos". Daí, reforça-se a árdua tarefa do historiador de "escovar" cotidianamente "a história a contrapelo".

\section{Referências}

BEMVINDO, Vitor. Por uma História da Educação Politécnica: concepções, experiências e perspectivas. 2016. Tese (Doutorado em Educação) - Programa de Pós-Graduação em Educação, Universidade Federal Fluminense.

BENJAMIN, Walter. Magia e Técnica, Arte e Política: ensaios sobre literatura e história da cultura. São Paulo: Editora Brasiliense, 1996.

CIAVATTA, Maria. Mediações históricas de trabalho e educação. Gênese e disputa na formação dos trabalhadores (Rio de Janeiro, 1930-60). Rio de Janeiro: Editora Lamparina, 2009.

ENGELS, Friedrich. Prefácio à terceira edição. In: MARX, K. 018 de Brumário de Luís Bonaparte. São Paulo: Boitempo, 2011. 
FONTANA, Joseph. História: análise do passado e projeto social. Bauru, SP: EDUSC, 1998.

GRAMSCI, Antonio. Concepção Dialética da História. Rio de Janeiro: Civilização Brasileira, 1978.

HOBSBAWM, Eric. Sobre História. São Paulo: Companhia das Letras, 1999.

KONDER, Leandro. "Limites e possibilidades de Marx e sua dialética para a leitura da história neste início de século". In: FRIGOTTO, Gaudêncio; CIAVATTA, Maria (org.). Teoria e Educação no labirinto do Capital. São Paulo: Expressão Popular, 2014.

KONDER, Leandro. O que é Dialética? São Paulo: Editora Brasiliense, 1984.

LÖWY, Michael. Walter Benjamin: aviso de incêndio. Uma leitura das teses "Sobre o conceito da história". São Paulo: Boitempo, 2012.

MARX, Karl. Contribuição à Crítica da Economia Política. São Paulo: Expressão Popular. 2008.

MARX, Karl. O 18 de Brumário de Luís Bonaparte. São Paulo: Boitempo, 2011.

MARX Karl.; ENGELS, Friedrich. A ideologia alemã. São Paulo: Boitempo, 2007.

MARX Karl.; ENGELS, Friedrich. Manifesto Comunista. São Paulo: Boitempo, 2010.

WILLIAMS, Raymond. Marxismo e Literatura. Rio de Janeiro: Zahar Editores, 1979.

WOOD, Ellen. "O que é a agenda pós-moderna". In: WOOD, Ellen; FOSTER, John B. Em defesa da História: marxismo e pós-modernismo. Rio de Janeiro: Jorge Zahar Editores, 1999. 